\title{
Comparison of the Contaminants in the Wastewater Produced in the Ex Situ Underground Ortho- and Meta-Lignite Gasification
}

\author{
Krzysztof Kapusta $\mathbb{D} \cdot$ Krzysztof Stańczyk • \\ Marian Wiatowski
}

Received: 26 March 2019 / Accepted: 31 July 2019/Published online: 10 August 2019

(C) The Author(s) 2019

\begin{abstract}
This work comprises results of the laboratory tests on formation and potential release of contaminants from underground gasification of lignites. Four large scale and multi-day trials were carried out using exsitu gasification facilities. Two different kinds of lignite were tested, i.e. Velenje lignite (Slovenia) and Oltenia lignite (Romania). Gasification tests were conducted in the artificial coal seams under two distinct pressure regimes - atmospheric and high pressure regime (35 bar and 10 bar for the Velenje and Oltenia samples respectively). The UCG wastewater samples were periodically collected from the gas purification module to measure the rate of the wastewater and contaminants production at each phase of the experiment and to assess the effect of gasification pressure and lignite physicochemical properties. The group of target contaminants included: phenols, aromatic hydrocarbons, and some non-specific water parameters. The effect of gasification pressure was confirmed, especially for BTEX and phenols and significant drops in the contents of these compounds were observed at elevated pressures. The effect of pressure was more pronounced for the geologically older coal (Velenje), i.e. drop in the average concentrations from $1994 \mu \mathrm{g} / \mathrm{l}$ (atmospheric) to $804 \mu \mathrm{g} / 1$ (35 bar) and from $733 \mathrm{mg} / \mathrm{l}$ (atmospheric) to $17 \mathrm{mg} / \mathrm{l}$ (35 bar) for BTEX and total phenols, respectively. The differences in the macromolecular structure and ash content of the
\end{abstract}

K. Kapusta $(\bowtie) \cdot$ K. Stańczyk $\cdot$ M. Wiatowski

Department of Energy Saving and Air Protection, Główny Instytut Górnictwa (Central Mining Institute), Plac Gwarków 1,

40-166 Katowice, Poland

e-mail: kkapusta@gig.eu both coals were found to be the main reason behind the differences in the contents of organic and inorganic species respectively. The study also shown that composition of UCG wastewaters significantly varied over the time of the particular experiments, which reflected changes in the gasification thermodynamic conditions and development of oxidation and pyrolysis zones. During the atmospheric gasification experiments, the values of BTEX for the Velenje lignite dropped from $3434 \mu \mathrm{g} / \mathrm{l}$ to $1364 \mu \mathrm{g} / \mathrm{l}$ and for the Oltenia lignite from $1833 \mu \mathrm{g} / \mathrm{l}$ to $978 \mu \mathrm{g} / \mathrm{l}$. A similar downward trend in the concentrations of BTEX was observed for the pressurized experiments. For the Velenje trial a drop from $1111.6 \mu \mathrm{g} / \mathrm{l}$ to $211.2 \mu \mathrm{g} / \mathrm{l}$ and for the Oltenia - from $1695 \mu \mathrm{g} / \mathrm{l}$ to $688 \mu \mathrm{g} / \mathrm{l}$ was observed. Concentrations of phenolic compounds during the atmospheric gasification experiments varied significantly during both atmospheric trials and no significant trends were noticed.

Keywords Gasification · Wastewater Gasification · Underground coal gasification

\section{Introduction}

Underground coal gasification is a conversion and extraction process for the production of useful synthetic product gas from an in-situ coal seam, to use in power generation, heat production or as a chemical feedstock. The process has been developed over more than a century and many aspects of the process are well understood (Couch 2009; 
Friedmann et al. 2009; Shafirovich and Varma 2009; Bhutto et al. 2013; Perkins 2018a, b). Apart from the high economic potentials, UCG may have a site-specific environmental impact, including pollution of shallow aquifers (Sury et al. 2004). Pollution of groundwater is considered to be the most serious possible negative environmental impact of underground coal gasification process. The UCG operation is inevitably related to the formation of hazardous environmental contaminants, as a result of the many heterogeneous and homogenous reactions that occur in the oxidation, reduction and pyrolysis zones that develop along the gasification channel. These toxic substances can be introduced into the groundwater at different phases of UCG (Kapusta et al. 2013; Liu et al. 2007). During the production phase, operating below the hydrostatic pressure can effectively control migration of contaminants (Burton et al. 2006). Under such conditions, the groundwater influx is towards the cavity, which prevents gas migration to the surrounding rock masses. The main problems during the production phase, however, are the post-processing effluents that are collected in the different modules of the surface gas processing system. These effluents, if not treated appropriately, can pose a serious environmental risk to surface waters. Experimental simulations and field studies on the formation and migration of contaminants around the UCG test sites identified a broad range of hazardous species (Kapusta and Stańczyk 2011; Edgar et al. 1981; Walters and Niemczyk 1984; DeGraeve et al. 1980; Shackley et al. 2006; Stuermer et al. 1982; Yang 2009; Smoliński et al. 2013). The major organic groundwater pollutants are typically phenolic compounds. In addition, benzene (with its alkyl derivatives-BTEX, polycyclic aromatic compounds (PAHs) and Nheterocyclic compounds are the next groups of organic compounds produced as by-products during UCG.

Comparison of post-process UCG wastewater with wastewater from coking plants shows some similarities and may help in developing technology for efficient treatment of UCG organic contaminants (Maranon et al. 2008).

The aim of this research work was to investigate the influence of gasification conditions, effect of lignite type as well as effect of pressure on the composition of UCG wastewater.

\section{Materials and Methods}

\subsection{Large-Scale Gasification Experiments and Lignite} Properties

Four large-scale experimental simulations of UCG process in surface conditions were carried out. The experiments involved tests on two different lignites, i.e. Velenje (Slovenia) and Oltenia (Romania). For each type of lignite, two gasification experiments were conducted-one atmospheric pressure and one at elevated pressure. During the pressurized tests, the gasification pressure was approximate to the natural hydrostatic pressures (geological depths) of the coal seams, from which the samples were extracted, i.e. $100 \mathrm{~m}$ and $350 \mathrm{~m}$ for the Oltenia and Velenje samples, respectively. The general characteristics of the gasification experiments are presented in Table 1. The pictures of atmospheric and pressurized UCG installations are presented in Fig. 1. The dimensions of the artificial coals seams for atmospheric and pressurized UCG experiments are presented in Figs. 2 and 3 respectively. Detailed descriptions of the experimental installations used are presented elsewhere (Wiatowski et al. 2019; Kapusta et al. 2016).

The atmospheric pressure gasification tests facility is equipped with a maximum of 20 thermocouples installed inside the reactor to record the temperature profiles. The thermocouples Nos. 1-6, 9-13, 15-20, depending on experimental assumptions, are usually located inside the coal seam. The thermocouples denoted as 14 and 21 are installed in the surrounding stratum, behind the coal seam (Fig. 2). Distributions of temperatures in the high pressure gasification tests stand are controlled by a maximum of 14 high-temperature thermocouples (Pt10Rh-Pt). Thermocouples T1-T7 are located in the gasification channel and thermocouples T8T14 in the roof strata (Fig. 3). The number of thermocouples used in the particular gasification tests may differ depending on process assumptions, coal properties and seam geometry. Such situation took place in the case of the four gasification tests presented in this study.

Results of proximate and ultimate analyses for colas under study are presented in Table 2. All analyses were 
Table 1 General characteristics of gasification experiments

\begin{tabular}{lllll}
\hline Parameter & Experiment No. & & & \\
\cline { 2 - 5 } & 1 & 2 & 3 & 4 \\
\hline Origin & Premogovnik Velenje (SLO) & Oltenia (RO) & Premogovnik Velenje (SLO) & Oltenia (RO) \\
Gasification reagent & $\mathrm{O}_{2}$ & $\mathrm{O}_{2} /$ steam & $\mathrm{O}_{2}$ & $\mathrm{O}_{2}$ \\
Gasification pressure & Atmospheric & Atmospheric & $35 \mathrm{bar}$ & $10 \mathrm{bar}$ \\
Coal seam dimensions & $0.7 \times 0.7 \times 6.0 \mathrm{~m}$ & $0.7 \times 0.7 \times 6.0 \mathrm{~m}$ & $0.4 \times 0.4 \times 3.5 \mathrm{~m}$ & $0.4 \times 0.4 \times 3.5 \mathrm{~m}$ \\
Experiment duration, $\mathrm{h}$ & 120 & 96 & 72 & 72 \\
\hline
\end{tabular}

performed by Department of Solid Fuels Quality Assessment of Central Mining Institute (ISO/IEC 17025 accreditation certificate).

\subsection{Sampling and Characteristics of UCG Wastewater}

The raw UCG product gas contains water vapour, originating mainly from the evaporation of coal moisture, the coal-pyrolysis process (pyrogenic water) or undesired hydrogen combustion. This gas moisture tends to condense onto the cooler parts of the installations, such as the internal surfaces of gas pipelines or in particular devices of the gastreatment module. To prevent environmental pollution during the UCG operations, the resulting postgasification water condensates are systematically collected and transported for off-site treatment. Post-processing waters produced in water scrubbers were periodically sampled within the whole course of all the gasification experiments in order to measure the rate of the wastewater and contaminants production at any phase of the experiment and to correlate the type and concentrations of produced contaminants with the coal characteristics and process parameters (e.g. effect of pressure). After averaging, the UCG water was sampled and transported to the laboratory for chemical analyses. Coal tars and other undissolved residues were removed from the UCG water by filtering and the filtrates were subsequently stored at $4{ }^{\circ} \mathrm{C}$ until analysed.

The organic analysis of the effluents included phenolics and benzene with its three alkyl homologs toluene, ethylbenzene and xylene (BTEX). The conductivity, $\mathrm{pH}$, biological oxygen demand $\left(\mathrm{BOD}_{5}\right)$, chemical oxygen demand $\left(\mathrm{COD}_{\mathrm{Cr}}\right)$ and total organic carbon (TOC) were additionally determined in the representative post-gasification effluents as typical nonspecific industrial wastewater parameters. The chemical analyses were performed applying standard analytical methods. Electrochemical methods, i.e. potentiometry and conductometry, were applied to determine the reaction $(\mathrm{pH})$ and the conductivity of the condensates, respectively. For the analysis of benzene and its derivatives (BTEX) and phenols, the gas chromatography headspace method using an Agilent Technologies $7890 \mathrm{~A}$ chromatograph coupled with a static headspace auto sampler Agilent 7697A and FID

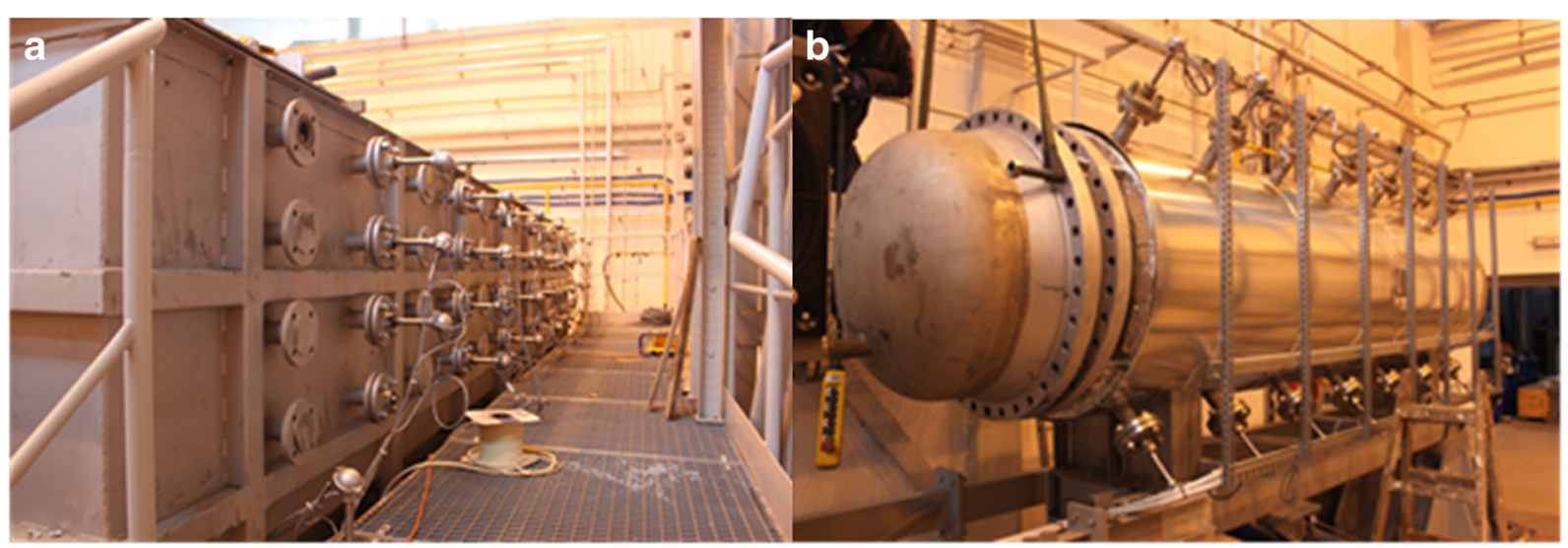

Fig. 1 Experimental installations used for the UCG tests. a Atmospheric pressure. b Pressurised 


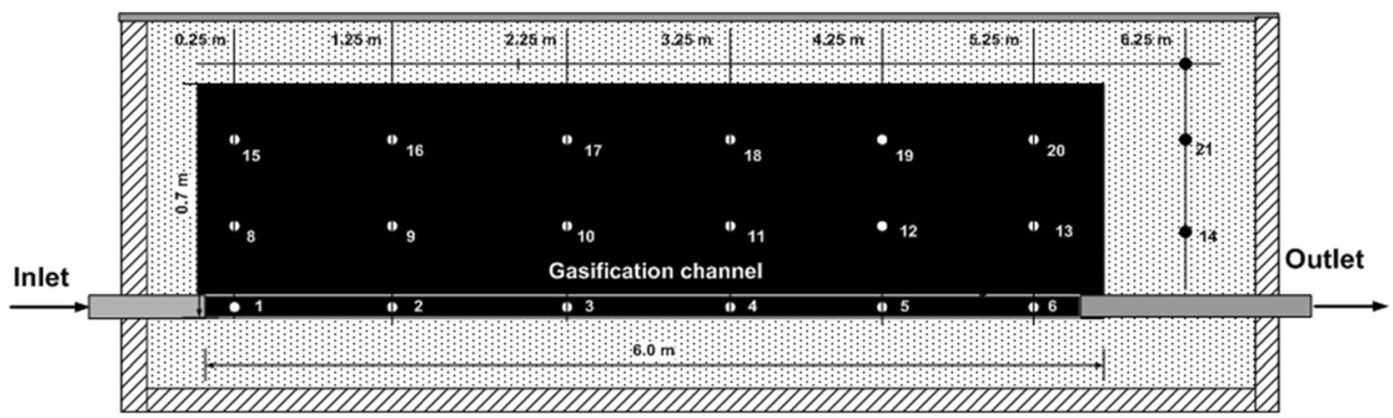

(a)

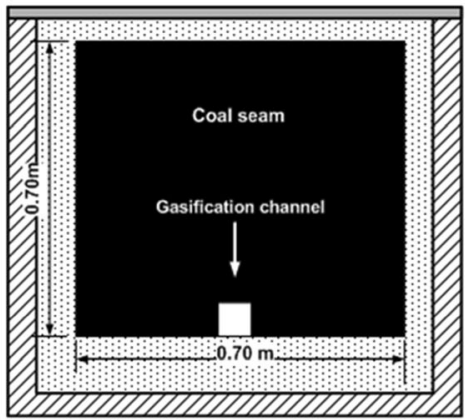

(b)

Fig. 2 The dimensions of artificial coal seams used for the atmospheric pressure UCG tests (proportions are not respected). a Side crosssection. b Vertical cross-section

detector was applied. The chromatographic column was DB-5MS ( $30 \mathrm{~m}, 0.25 \mathrm{~mm}, 0.5 \mu \mathrm{m})$ and helium was used as the carrier gas at $1.0 \mathrm{ml} / \mathrm{min}$.

\section{Results and Discussion}

\subsection{Temperature Distribution}

\subsubsection{Atmospheric Pressure Gasification Tests}

Distributions of temperatures in the gasification channel and two levels above the bottom of the seam over the course of the atmospheric pressure experiments are presented in Figs. 4 and 5 for the Velenje and Oltenia experiments respectively.

The maximum gasification temperature during Velenje trial was about $1300{ }^{\circ} \mathrm{C}$ and it was recorded by the thermocouple located $0.3 \mathrm{~m}$ above the gasification channel, after approx. $24 \mathrm{~h}$ of the gasification run. For the Oltenia atmospheric pressure experiment, the maximum gasification temperature was about $1380{ }^{\circ} \mathrm{C}$ and it was recorded by the thermocouple located $0.3 \mathrm{~m}$ above the gasification channel, at the early stage of the process (Fig. 5b).

\subsubsection{Pressurized Gasification Tests}

Distributions of temperatures in the gasification channel and in roof strata over the course of the pressurized experiments are presented in Figs. 6 and 7 for Oltenia and Velenje experiments respectively.

The maximum gasification temperatures during both experiments were approximately $850{ }^{\circ} \mathrm{C}$ and they were recorded in the roof strata. However, it must be emphasized that the actual process temperatures were significantly higher, but due to insulation phenomena (refractory materials used and thermocouples' ceramic casings), the records had lower values. Analysis of the temperatures indicates that during the experiments, temperatures in the bottom strata (gasification channel) were about 150 to $200{ }^{\circ} \mathrm{C}$ lower than the temperatures in the upper levels of the cavity. This phenomenon confirms that the post-gasification ash/slag and molten roof may effectively insulate against heat conduction to the bottom strata during the UCG operations. 
Fig. 3 The dimensions of artificial coal seams used for the pressurized UCG tests

(proportions are not respected). a Side cross-section. b Vertical cross-section

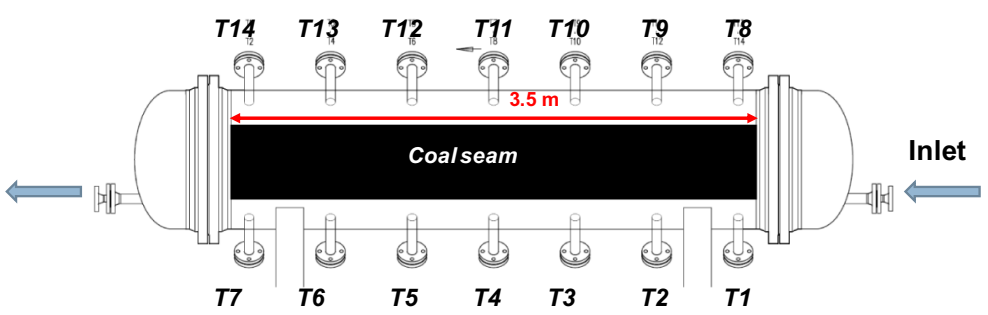

(a)

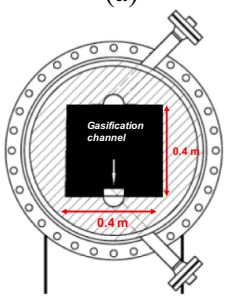

(b) (a)

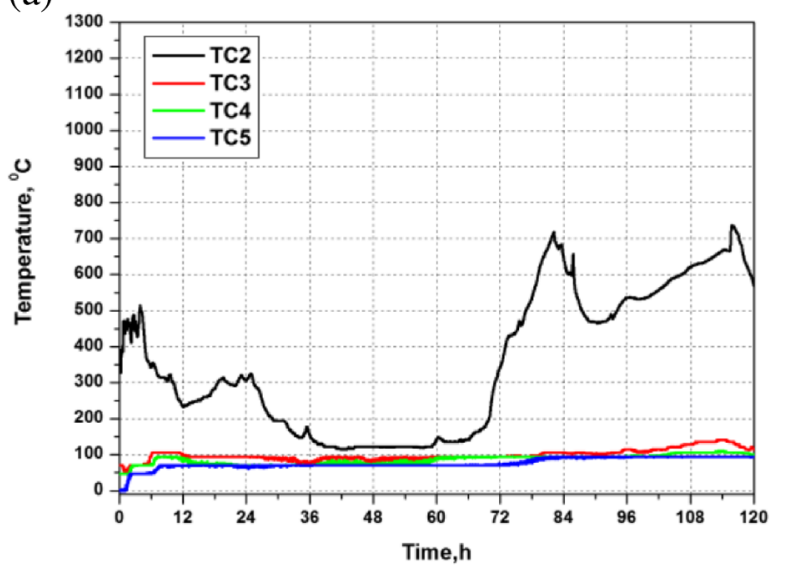

(c)

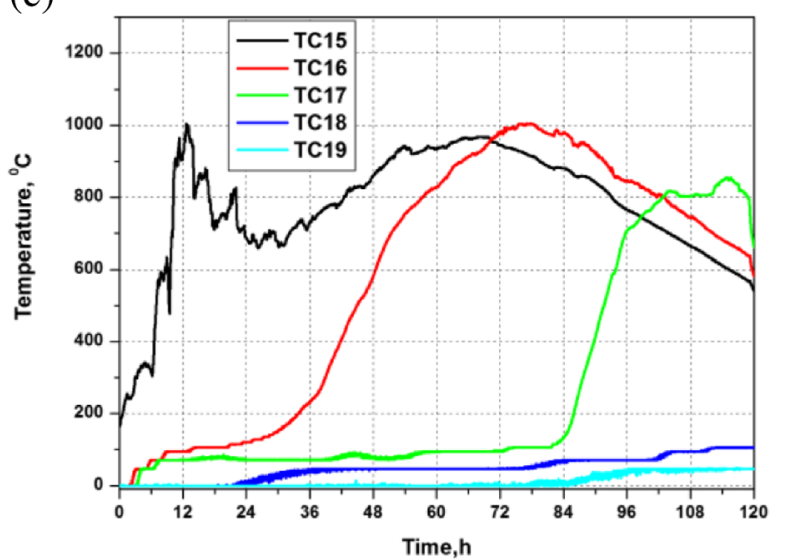

(b)

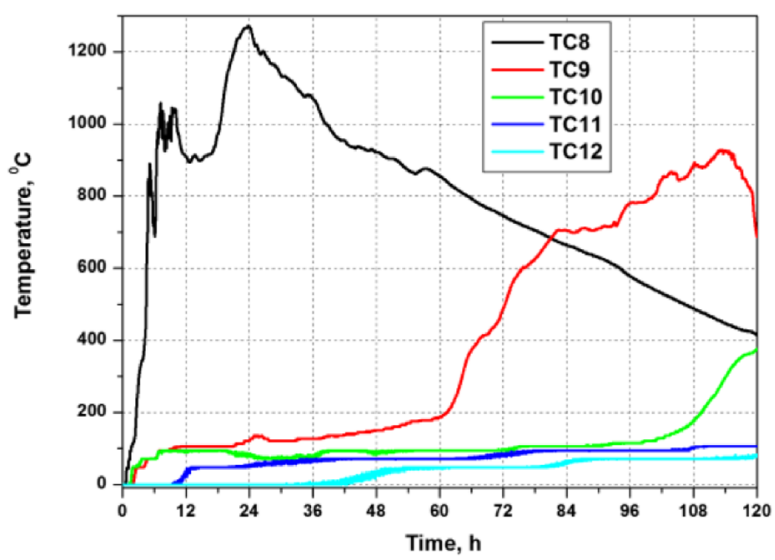

Fig. 4 Distributions of temperatures during the atmospheric gasification experiment with Velenje lignite. a Gasification channel. b $0.3 \mathrm{~m}$ above seam bottom. c $0.6 \mathrm{~m}$ above seam bottom 
(a)

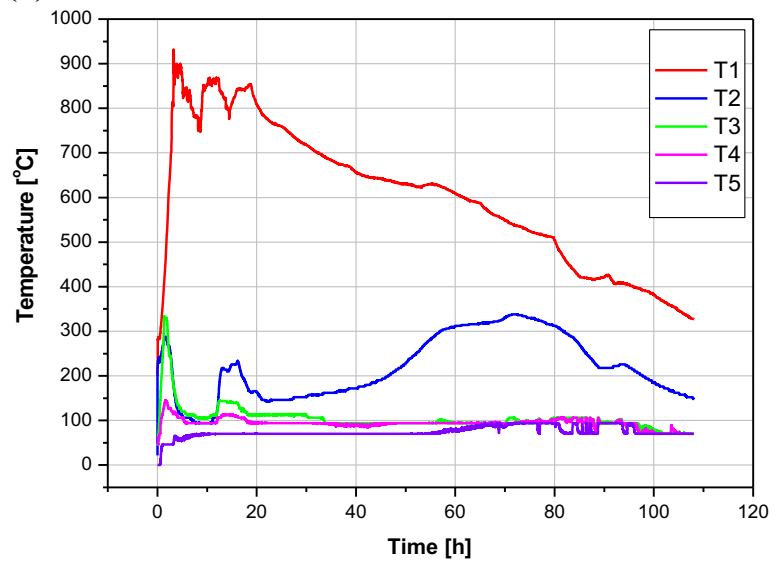

(b)

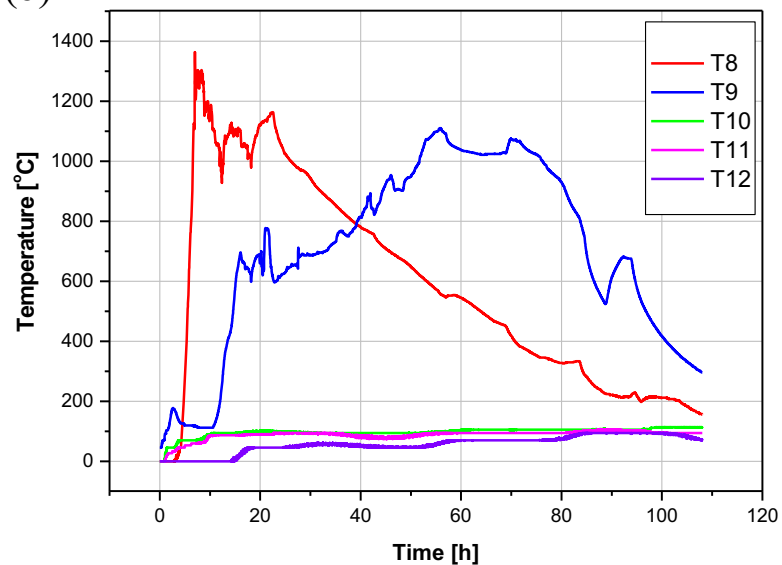

Fig. 5 Distributions of temperatures during the atmospheric gasification experiment with Oltenia lignite. a Gasification channel. b $0.3 \mathrm{~m}$ above seam bottom. c $0.6 \mathrm{~m}$ above seam bottom

3.2 Changes in the Wastewater Composition Along with the Gasification Progress

The values of measured wastewater parameters during the course of all experiments are presented in the Tables 3, 4, 5, and 6. As can be concluded from the tables, values of the measured physicochemical parameters significantly varied over the time of the particular gasification experiments. For the organic contaminants, these variations reflected changes in the gasification conditions (temperature) and development of the oxidation and pyrolysis zones over the experiments. The analysis of the presented results indicates a general decreasing trend for the concentrations of most of the measured compounds along with the gasification

(a)

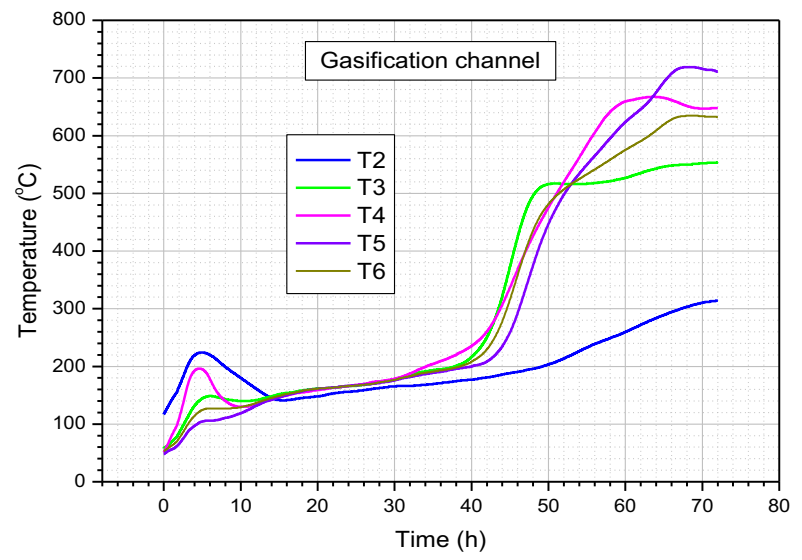

progress. During the UCG process, the contaminants are generated mostly as a result of coal pyrolysis (thermal decomposition). In the oxidation zone, organic compounds are cracked and oxidized to gas products like $\mathrm{CO}, \mathrm{H}_{2}$, and $\mathrm{CH}_{4}$. The final concentrations depend mostly on the mutual proportions of the areas of pyrolysis and oxidation zones. The results obtained indicate a gradual increase in the decomposition of pyrolysis products over the courses of the experiments conducted. During the atmospheric gasification experiments, the values of BTEX for the Velenje lignite dropped from 3434 to $1364 \mu \mathrm{g} / \mathrm{l}$ and for the Oltenia lignite from 1833 to $978 \mu \mathrm{g} / \mathrm{l}$. A similar downward trend in the concentrations of BTEX was observed for the pressurized experiments. For the Velenje trial, a drop from 1111.6

(b)

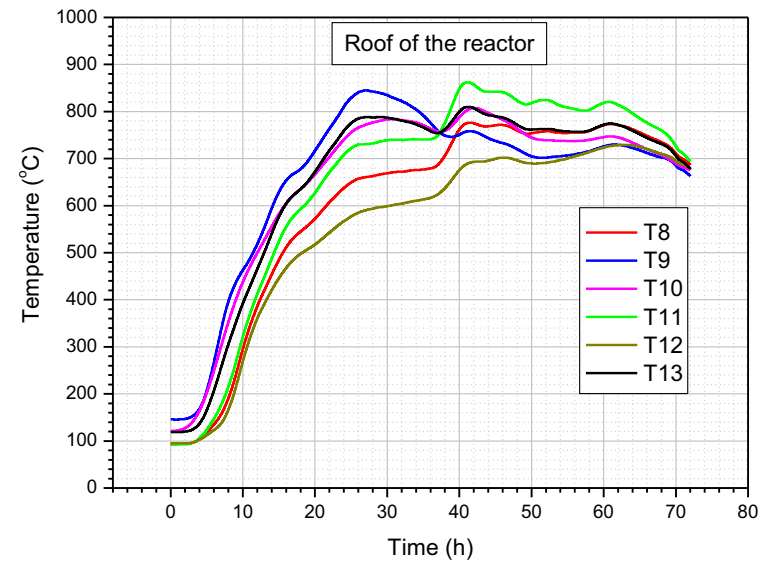

Fig. 6 Distributions of temperatures during Oltenia 10 bar experiment. a Gasification channel. b Roof strata 
(a)

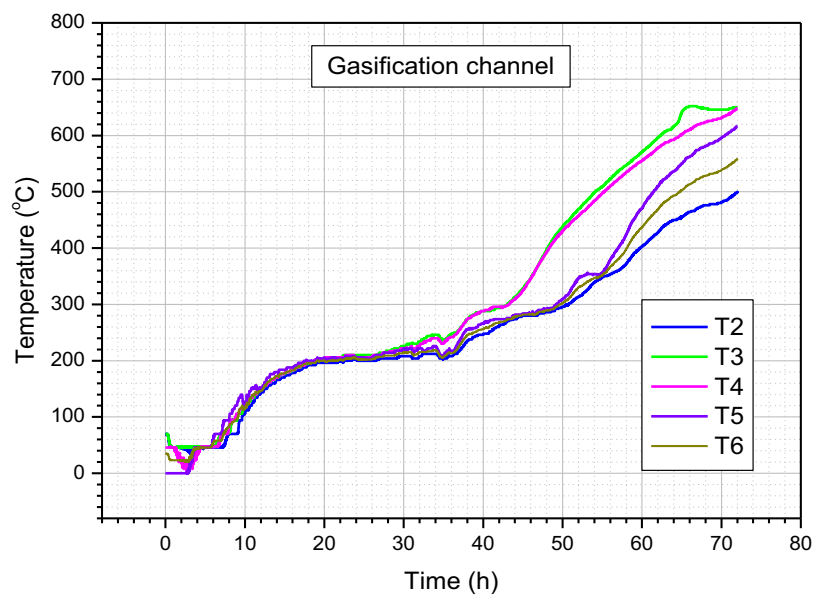

(b)

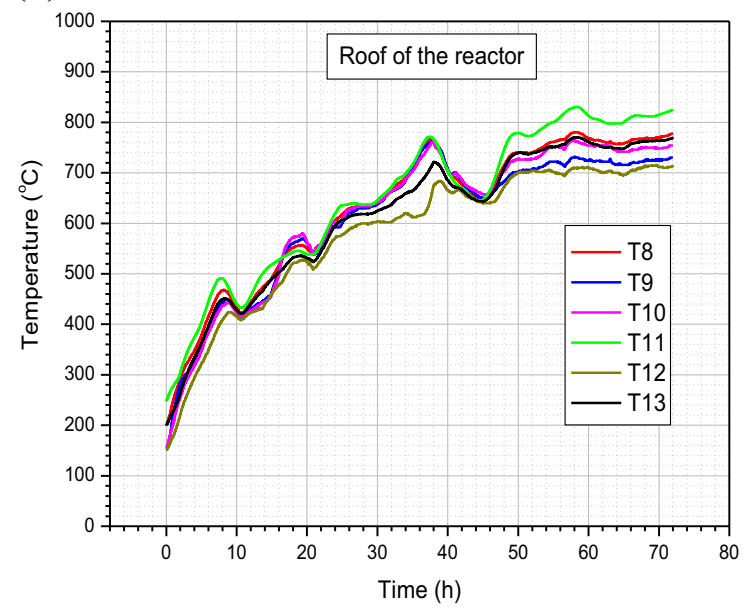

Fig. 7 Distributions of temperatures during 35 bar Velenje experiment. a Gasification channel. b Roof strata

to $211.2 \mu \mathrm{g} / \mathrm{l}$ and for the Oltenia from 1695 to $688 \mu \mathrm{g} / \mathrm{l}$ was observed. Concentrations of phenolic compounds during the atmospheric gasification experiments varied significantly during both atmospheric trials and no significant trends were noticed. Contrary to the atmospheric processes, during the pressurized tests, similarly to the

Table 2 Proximate and ultimate characteristics of lignites used for ex-situ gasification tests

\begin{tabular}{lll}
\hline Parameter & \multicolumn{2}{l}{ Lignite sample } \\
\cline { 2 - 3 } & Velenje & Oltenia \\
\hline As received & & \\
Total moisture $\mathrm{W}_{\mathrm{t}}^{\mathrm{r}}, \%$ & 31.62 & 45.64 \\
Ash $\mathrm{A}_{\mathrm{t}}^{\mathrm{r}}, \%$ & 4.29 & 8.86 \\
Volatiles $\mathrm{V}^{\mathrm{r}}, \%$ & 43.67 & 25.78 \\
Total sulphur $\mathrm{S}_{\mathrm{t}}^{\mathrm{r}}, \%$ & 0.51 & 1.49 \\
Calorific value $\mathrm{Q}_{\mathrm{i}}^{\mathrm{r}}, \mathrm{kJ} / \mathrm{kg}$ & 13,615 & 10,642 \\
& & \\
Analytical & & \\
Moisture $\mathrm{W}^{\mathrm{a}}, \%$ & 11.13 & 11.49 \\
Ash $\mathrm{A}^{\mathrm{a}}, \%$ & 5.57 & 14.42 \\
Volatiles $\mathrm{V}^{\mathrm{a}}, \%$ & 56.76 & 41.98 \\
Heat of combustion $\mathrm{Q}_{\mathrm{s}}^{\mathrm{a}}, \mathrm{kJ} / \mathrm{kg}$ & 19,719 & 20,001 \\
Calorific value $\mathrm{Q}_{\mathrm{i}}^{\mathrm{a}}, \mathrm{kJ} / \mathrm{kg}$ & 18,427 & 18,860 \\
Total sulphur $\mathrm{S}^{\mathrm{a}}, \%$ & 0.66 & 2.43 \\
Carbon $\mathrm{C}_{\mathrm{t}}^{\mathrm{a}}, \%$ & 49.86 & 49.49 \\
Hydrogen $\mathrm{H}_{\mathrm{t}}^{\mathrm{a}}, \%$ & 4.67 & 3.94 \\
Nitrogen $\mathrm{N}^{\mathrm{a}}, \%$ & 0.64 & 1.34 \\
Oxygen $\mathrm{O}_{\mathrm{d}}{ }^{\mathrm{a}}, \%$ & 27.83 & 17.12 \\
\hline
\end{tabular}

concentrations of BTEX, decreasing trends in the concentration of phenols were observed. For the Velenje 35 bar trial, a drop from 25.11 to $4.13 \mathrm{mg} / \mathrm{l}$ and for the Oltenia 10 bar tests from 192.9 to $7.7 \mathrm{mg} / 1$ in the concentration of total phenols was observed.

As can be seen from Tables 3, 4, 5, and 6, the values of the non-specific parameters (conductivity, BOD-5 and COD) were characterized by a high variability. The values of these parameters depend on many inorganic and organic constituents, often governed by their solubility in water; hence, an accurate interpretation of the results obtained is difficult.

\subsection{Effect of Gasification Pressure}

The average values of the parameters determined in the UCG wastewaters originating from all ex-situ gasification experiments are presented in Table 7.

For the both lignites under study, the effect of gasification pressure on the chemical composition of wastewater is evident. As regards the main groups of the organic contaminants under investigation, i.e. BTEX and phenols, drops in the concentrations of these compounds were observed with the increase in gasification pressure. As can be seen from Table 7, the effect of pressure was more pronounced for the Velenje lignite, i.e. drop in the average concentrations from $1994 \mu \mathrm{g} / \mathrm{l}$ (atmospheric) to $804 \mu \mathrm{g} / \mathrm{l}$ (35 bar) and from $733 \mathrm{mg} / \mathrm{l}$ (atmospheric) to $17 \mathrm{mg} / \mathrm{l}$ (35 bar) for BTEX and total phenols, respectively. For the experiments with Oltenia lignite, the average concentrations of BTEX dropped from 1784 to $1562 \mu \mathrm{g} / \mathrm{l}$ and for total phenols it dropped 
Table 3 Changes of selected wastewaters parameters over the lignite Velenje atmospheric gasification experiment

\begin{tabular}{|c|c|c|c|c|c|c|c|}
\hline \multirow[t]{2}{*}{ Parameter } & \multirow[t]{2}{*}{ Unit } & \multicolumn{6}{|l|}{ Time, $\mathrm{h}$} \\
\hline & & 20 & 40 & 60 & 80 & 100 & 120 \\
\hline Conductivity & $\mu \mathrm{S} / \mathrm{cm}$ & 1060 & 1500 & 2320 & 1690 & 3140 & 5160 \\
\hline $\mathrm{pH}$ & $\mathrm{pH}$ & 7 & 7.4 & 7.4 & 7 & 7.4 & 7.8 \\
\hline BOD-5 & $\mathrm{mg} / \mathrm{l} \mathrm{O}_{2}$ & 2670 & 3280 & 2420 & 1870 & 4400 & 11,600 \\
\hline $\mathrm{COD}(\mathrm{Cr})$ & $\mathrm{mg} / \mathrm{l} \mathrm{O}_{2}$ & 5320 & 6010 & 5060 & 4380 & 8740 & 18,850 \\
\hline TOC & $\mathrm{mg} / \mathrm{l}$ & 1800 & 2200 & 1700 & 1300 & 3000 & 4400 \\
\hline Benzene & $\mu \mathrm{g} / 1$ & 2435 & 1322 & 1092 & 744 & 895 & 647 \\
\hline Toluene & $\mu \mathrm{g} / 1$ & 481 & 378 & 269 & 233 & 494 & 283 \\
\hline Ethylbenzene & $\mu \mathrm{g} / 1$ & 222 & 227 & 178 & 175 & 360 & 270 \\
\hline m,p-Xylene & $\mu \mathrm{g} / \mathrm{l}$ & 98 & 74 & 62 & 60 & 123 & 71 \\
\hline o-Xylene & $\mu \mathrm{g} / 1$ & 198 & 133 & 98 & 79 & 170 & 93 \\
\hline BTEX & $\mu \mathrm{g} / 1$ & 3434 & 2134 & 1699 & 1291 & 2042 & 1364 \\
\hline Phenol & $\mathrm{mg} / \mathrm{l}$ & 335.89 & 427.29 & 370.19 & 283 & 804.13 & 637.67 \\
\hline o-Cresol & $\mathrm{mg} / 1$ & 80.26 & 120.44 & 95.31 & 76.03 & 176.79 & 146.28 \\
\hline m,p-Cresol & $\mathrm{mg} / \mathrm{l}$ & 94.01 & 129.85 & 112.8 & 90.13 & 223.64 & 191.98 \\
\hline Total phenol & $\mathrm{mg} / \mathrm{l}$ & 510.16 & 677.58 & 578.3 & 449.16 & 1204.56 & 975.93 \\
\hline
\end{tabular}

from 246 to $201 \mathrm{mg} / \mathrm{l}$ when the gasification pressure increased from atmospheric to 10 bar. As the increase in gasification pressure usually leads to the intensification

Table 4 Changes of selected wastewaters parameters over the lignite Oltenia atmospheric gasification experiment

\begin{tabular}{|c|c|c|c|c|c|}
\hline \multirow[t]{2}{*}{ Parameter } & \multirow[t]{2}{*}{ Unit } & \multicolumn{4}{|c|}{ Time, h } \\
\hline & & 20 & 40 & 60 & 80 \\
\hline Conductivity & $\mu \mathrm{S} / \mathrm{cm}$ & 2070 & 4390 & 3740 & 2420 \\
\hline $\mathrm{pH}$ & $\mathrm{pH}$ & 7.7 & 7.8 & 7.7 & 7.5 \\
\hline BOD-5 & $\mathrm{mg} / \mathrm{l} \mathrm{O}_{2}$ & 750 & 1070 & 1320 & 1050 \\
\hline $\mathrm{COD}(\mathrm{Cr})$ & $\mathrm{mg} / \mathrm{l} \mathrm{O}_{2}$ & 1520 & 2060 & 2520 & 1940 \\
\hline TOC & $\mathrm{mg} / \mathrm{l}$ & 620 & 1000 & 1100 & 810 \\
\hline Benzene & $\mu \mathrm{g} / 1$ & 1442 & 1464 & 1437 & 418 \\
\hline Toluene & $\mu \mathrm{g} / 1$ & 253 & 369 & 275 & 211 \\
\hline Ethylbenzene & $\mu \mathrm{g} / 1$ & 97 & 341 & 331 & 285 \\
\hline m,p-Xylene & $\mu \mathrm{g} / 1$ & n.w & n.w & n.w & n.w \\
\hline o-Xylene & $\mu \mathrm{g} / \mathrm{l}$ & 41 & 51 & 57 & 64 \\
\hline BTEX & $\mu \mathrm{g} / 1$ & 1833 & 2225 & 2100 & 978 \\
\hline Phenol & $\mathrm{mg} / \mathrm{l}$ & 117.9 & 155.90 & 169.80 & 126.60 \\
\hline o-Cresol & $\mathrm{mg} / \mathrm{l}$ & 29.20 & 56.20 & 65.50 & 51.80 \\
\hline m,p-Cresol & $\mathrm{mg} / \mathrm{l}$ & 37.00 & 56.30 & 66.30 & 50.40 \\
\hline Total Phenol & $\mathrm{mg} / \mathrm{l}$ & 184.1 & 268.4 & 301.6 & 228.8 \\
\hline
\end{tabular}

of tar cracking phenomena, the increased gasification pressure was the main factor responsible for the drops in the concentrations of organic compound in the analysed wastewaters.

The effect of gasification pressure is also pronounced for the values of the remaining parameters of the UCG wastewaters. For the determined non-specific parameters, i.e. conductivity, BOD-5 and COD, significant drops in the average values were observed when gasification pressure increased from atmospheric to 35 bar for Velenje lignite. On the contrary, in the case of Oltenia lignite gasification, the average values of these parameters significantly decreased (Table 7). For both lignites under study, the values of $\mathrm{pH}$ in the UCG wastewaters significantly dropped when gasification pressure increased, i.e. from 7.3 to 6 and from 7.7 to 5.1 for the Velenje and Oltenia experiments, respectively. Each of the lignites under investigation was gasified under the pressure adjusted to its natural hydrostatic pressure occurring in the seam. As a consequence, the gasification experiments were conducted under different pressures, i.e. 35 bar (Velenje) and 10 bar (Oltenia). Therefore, concluding on the influence of difference in gasification pressure between 10 and 35 bar is not feasible within this experimental study, because both gasification experiments were conducted using lignites of distinct physicochemical properties. 
Table 5 Changes of selected wastewaters parameters over the lignite Velenje 35 bar gasification experiment

\begin{tabular}{|c|c|c|c|c|c|}
\hline \multirow[t]{2}{*}{ Parameter } & \multirow[t]{2}{*}{ Unit } & \multicolumn{4}{|l|}{ Time, $\mathrm{h}$} \\
\hline & & 20 & 40 & 60 & 72 \\
\hline Conductivity & $\mu \mathrm{S} / \mathrm{cm}$ & 311 & 3870 & 1260 & 1640 \\
\hline $\mathrm{pH}$ & $\mathrm{pH}$ & 5.9 & 7.9 & 3.1 & 7.6 \\
\hline BOD-5 & $\mathrm{mg} / \mathrm{l} \mathrm{O}_{2}$ & 340 & 820 & 23 & 17 \\
\hline $\mathrm{COD}(\mathrm{Cr})$ & $\mathrm{mg} / \mathrm{l} \mathrm{O}_{2}$ & 791 & 1700 & 121 & 152 \\
\hline TOC & $\mathrm{mg} / \mathrm{l}$ & 190 & 430 & 33 & 15 \\
\hline Benzene & $\mu \mathrm{g} / 1$ & 833.8 & 951.6 & 151 & 112.7 \\
\hline Toluene & $\mu \mathrm{g} / 1$ & 166 & 400.2 & 68.8 & 65.6 \\
\hline Ethylbenzene & $\mu \mathrm{g} / 1$ & 20.1 & 60.2 & 8.5 & 8.8 \\
\hline m,p-Xylene & $\mu \mathrm{g} / 1$ & 15.9 & 95.2 & 10.1 & 10 \\
\hline o-Xylene & $\mu \mathrm{g} / 1$ & 75.8 & 132.9 & 15.6 & 14.1 \\
\hline BTEX & $\mu \mathrm{g} / 1$ & 1111.6 & 1640.1 & 254 & 211.2 \\
\hline Phenol & $\mathrm{mg} / \mathrm{l}$ & 15.82 & 8.75 & 6.88 & 2.95 \\
\hline o-Cresol & $\mathrm{mg} / \mathrm{l}$ & 5.19 & 10.05 & 1.56 & 0.65 \\
\hline m,p-Cresol & $\mathrm{mg} / \mathrm{l}$ & 4.1 & 10.39 & 1.45 & 0.53 \\
\hline Total phenol & $\mathrm{mg} / \mathrm{l}$ & 25.11 & 29.19 & 9.89 & 4.13 \\
\hline
\end{tabular}

\subsection{Effect of Lignite Type}

As can be concluded from the results presented in Table 7, the effect of lignite used on the values of physicochemical parameters of the wastewaters is evident. When analysing results obtained under the same pressure conditions (atmospheric experiments), for most of the organic compounds (or non-specific parameters correlated with the organic species, i.e. TOC, BOD-5, COD), significantly higher values were

Table 6 Changes of selected wastewaters parameters over the lignite Oltenia 10 bar gasification experiment

\begin{tabular}{|c|c|c|c|c|c|}
\hline \multirow[t]{2}{*}{ Parameter } & \multirow[t]{2}{*}{ Unit } & \multicolumn{4}{|c|}{ Time, $\mathrm{h}$} \\
\hline & & 20 & 40 & 60 & 72 \\
\hline Conductivity & $\mu \mathrm{S} / \mathrm{cm}$ & 2930 & 11,700 & 4580 & 1800 \\
\hline $\mathrm{pH}$ & $\mathrm{pH}$ & 2.6 & 7.7 & 7.2 & 2.9 \\
\hline BOD-5 & $\mathrm{mg} / \mathrm{l} \mathrm{O}_{2}$ & 1910 & 4940 & 1540 & 28 \\
\hline $\mathrm{COD}(\mathrm{Cr})$ & $\mathrm{mg} / \mathrm{l} \mathrm{O}_{2}$ & 3240 & 10,100 & 3100 & 266 \\
\hline TOC & $\mathrm{mg} / \mathrm{l}$ & 890 & 3200 & 860 & 50 \\
\hline Benzene & $\mu \mathrm{g} / 1$ & 1324 & 1543 & 1100 & 321 \\
\hline Toluene & $\mu \mathrm{g} / \mathrm{l}$ & 244 & 333 & 201 & 167 \\
\hline Ethylbenzene & $\mu \mathrm{g} / \mathrm{l}$ & 88 & 298 & 298 & 155 \\
\hline m,p-Xylene & $\mu \mathrm{g} / \mathrm{l}$ & 0 & 0 & 0 & 0 \\
\hline o-Xylene & $\mu \mathrm{g} / 1$ & 39 & 47 & 45 & 45 \\
\hline BTEX & $\mu \mathrm{g} / \mathrm{l}$ & 1695 & 2221 & 1644 & 688 \\
\hline Phenol & $\mathrm{mg} / \mathrm{l}$ & 121.2 & 355.90 & 78.40 & 5.20 \\
\hline o-Cresol & $\mathrm{mg} / \mathrm{l}$ & 28.50 & 101.20 & 34.50 & 1.20 \\
\hline m,p-Cresol & $\mathrm{mg} / \mathrm{l}$ & 43.20 & 123,3 & 33.20 & 1.30 \\
\hline Total phenol & $\mathrm{mg} / \mathrm{l}$ & 192.9 & 457.1 & 146.1 & 7.7 \\
\hline
\end{tabular}


Table 7 Average values of parameters determined in the UCG wastewaters in the experiments conducted

\begin{tabular}{|c|c|c|c|c|c|}
\hline \multirow[t]{2}{*}{ Parameter } & \multirow[t]{2}{*}{ Unit } & \multicolumn{2}{|l|}{ Lignite Velenje } & \multicolumn{2}{|l|}{ Lignite Oltenia } \\
\hline & & Atmospheric pressure & 35 bar pressure & Atmospheric pressure & 10 bar pressure \\
\hline Conductivity & $\mu \mathrm{S} / \mathrm{cm}$ & 2478 & 1770 & 3155 & 5253 \\
\hline $\mathrm{pH}$ & $\mathrm{pH}$ & 7.3 & 6 & 7.7 & 5.1 \\
\hline BOD-5 & $\mathrm{mg} / \mathrm{l} \mathrm{O}_{2}$ & 4373 & 300 & 1048 & 2105 \\
\hline $\mathrm{COD}(\mathrm{Cr})$ & $\mathrm{mg} / \mathrm{l} \mathrm{O}_{2}$ & 5060 & 691 & 2010 & 4177 \\
\hline TOC & $\mathrm{mg} / \mathrm{l}$ & 2400 & 167.0 & 882.5 & 1250 \\
\hline Benzene & $\mu \mathrm{g} / 1$ & 1189.2 & 512.3 & 1190.3 & 1072.0 \\
\hline Toluene & $\mu \mathrm{g} / \mathrm{l}$ & 356.3 & 175.2 & 277.0 & 236.3 \\
\hline Ethylbenzene & $\mu \mathrm{g} / 1$ & 238.7 & 24.4 & 263.5 & 209.8 \\
\hline m,p-Xylene & $\mu \mathrm{g} / \mathrm{l}$ & 81.3 & 32.8 & $<1$ & 0.0 \\
\hline o-Xylene & $\mu \mathrm{g} / 1$ & 128.5 & 59.6 & 53.3 & 44.0 \\
\hline Total BTEX & $\mu \mathrm{g} / 1$ & 1994 & 804 & 1784 & 1562.0 \\
\hline Phenol & $\mathrm{mg} / \mathrm{l}$ & 476.4 & 8.6 & 142.6 & 140.2 \\
\hline o-Cresol & $\mathrm{mg} / \mathrm{l}$ & 115.9 & 4.4 & 50.7 & 41.4 \\
\hline m,p-Cresol & $\mathrm{mg} / \mathrm{l}$ & 140.4 & 4.1 & 52.5 & 25.9 \\
\hline Total phenol & $\mathrm{mg} / \mathrm{l}$ & 733 & 17 & 246 & 201 \\
\hline
\end{tabular}

observed in the wastewaters from Velenje lignite experiment. It could result from differences in the macromolecular structure of the both lignites. Velenje lignite is also characterized by higher contents of volatiles (Table 2), which leads to the increased yields of organic, tarous compounds from the mass of gasified lignite. The higher values of conductivity in the wastewaters from Oltenia trial derived from the higher concentrations of selected ionic inorganic species. This could be due to a greater ash content of the Oltenia coal, i.e. $8.9 \%$ compared to $4.3 \%$ of ash in the Velenje coal (on as-received basis). The presence of ionic constituents in the UCG wastewater is mainly from leaching of the postgasification ash and other solid-particles (char) captured in the gas purification system.

\subsection{Comparison of the Wastewater from UCG}

and Wastewater from Coke Plant and Recommendation for Possible Cleaning Technology

Some parameters of wastewater from coke plants are very similar to that of UCG process. For example, chemical oxygen demand $\left(\mathrm{COD}_{\mathrm{Cr}}\right)$ for the coke plant wastewater in Australia, Germany, China and Spain (Maranon et al. 2008) is in the range of $630-6500 \mathrm{mg} /$ 1 and in our UCG research in the range of $691-5060 \mathrm{mg} /$ 1. Another example may be phenolic compounds, which for wastewater from coke plants are in the range of $50-1200 \mathrm{mg} / \mathrm{l}$ and in our UCG research is in range of $17-733 \mathrm{mg} / \mathrm{l}$.

Due to the composition and specificity of contaminants occurring in the coke oven wastewater, its proper treatment requires the involvement of physical, chemical and biological methods. For example, sometimes physicochemical treatment for coke plant effluents is enough (Ghose 2002) but also more sophisticated methods after primary physicochemical treatment are tested (Ozyonar and Karagozogly 2015) and in many plants also biological methods are used (Li et al. 2003; Xuewen et al. 2013). The methods very probably could be used for UCG wastewater cleaning but it needs dedicated research and examinations.

\section{Conclusions}

1. Changes in the gasification conditions strongly influence the composition of wastewater from UCG process. The amount of organic compounds measured in UCG wastewater depends mainly on the thermodynamic conditions (temperature) and mutual proportions of the areas of pyrolysis and oxidation zones at given stage of the UCG process. The results obtained indicate a gradual increase in the 
decomposition of pyrolysis products over the courses of the experiments conducted. During the atmospheric gasification experiments, the values of BTEX for the Velenje lignite dropped from 3434 to $1364 \mu \mathrm{g} / \mathrm{l}$ and for the Oltenia lignite from 1833 to $978 \mu \mathrm{g} / \mathrm{l}$. Similar trends were observed for the pressurized experiments. It was found that concentrations of phenolic compounds during the atmospheric gasification experiments varied significantly during both atmospheric trials and no significant trends were noticed. During the pressurized tests, decreasing trends in the concentration of phenols were observed. For the Velenje 35 bar trial, a drop from 25.11 to $4.13 \mathrm{mg} / \mathrm{l}$ and for the Oltenia 10 bar tests from 192.9 to $7.7 \mathrm{mg} / \mathrm{l}$ in the concentration of total phenols was observed.

2. The effect of lignite properties on the values of physicochemical parameters of the UCG wastewaters is evident. When analysing results obtained under atmospheric pressure conditions, for most of the organic compounds investigated, significantly higher values were observed in the wastewaters from Velenje trial. As regards BTEX, the average concentrations were $1994 \mu \mathrm{g} / \mathrm{l}$ and $1784 \mu \mathrm{g} / \mathrm{l}$ for the Velenje and Oltenia experiments, respectively. The average concentration of phenol during Velenje trial was $733 \mathrm{mg} / \mathrm{l}$, compared to $246 \mathrm{mg} / \mathrm{l}$ obtained during Oltenia experiment. These differences resulted from distinct macromolecular structures and physicochemical properties of the both lignites, mainly content of volatile matter, which significantly affects the yields of tarous compounds from the mass of lignite. It was found that concentrations of inorganic species in UCG wastewater (higher values for Oltenia lignite) are positively correlated with the ash content in the gasified lignite. The presence of inorganic, ionic constituents in the UCG wastewater is mainly from leaching of the post-gasification ash and other solids (e.g. char) captured in the gas purification system.

3. For the both lignites under study, the effect of pressure on the concentrations of organic compounds (BTEX, phenols) was evident and it was more pronounced for the Velenje lignite, i.e. drop in the average concentrations from $1994 \mu \mathrm{g} / 1$ (atmospheric) to $804 \mu \mathrm{g} / \mathrm{l}$ (35 bar) and from $733 \mathrm{mg} / \mathrm{l}$ (atmospheric) to $17 \mathrm{mg} / \mathrm{l}$ (35 bar) for BTEX and total phenols, respectively. For the Oltenia lignite, the average concentrations of BTEX dropped from 1784 to $1562 \mu \mathrm{g} / \mathrm{l}$ and for total phenols it dropped from 246 to $201 \mathrm{mg} / \mathrm{l}$ when the gasification pressure increased from atmospheric to 10 bar. As the increase in gasification pressure usually leads to the intensification of tar cracking phenomena, the increased gasification pressure was the main reason behind the drops.

4. Comparison of the composition of wastewater from UCG and wastewater from coke oven plants shows many similarities. The values of COD and concentrations of phenols are comparable for both processes in spite of different feedstocks used in both processes. Taking into account these similarities, it seems to be reasonable to recommend the same purification techniques for UCG wastewater as were developed for the wastewaters from coking industry.

Acknowledgments The research presented in this paper was performed as a part of the project, Enhanced Coal Exploitation through Underground Gasification in European Lignite Mines, carried out with a financial grant by the Research Program of the Research Fund for Coal and Steel, grant agreement no. RFCR-CT2014-00003. The work was also partly supported by the Polish Ministry of Science and Higher Education. The authors are thankful to project coordinator-Institute for Studies and Power Engineering (ISPE), Romania and project partners: Complexul Energetic Oltenia and Premogovnik Velenje DD for lignite samples preparation.

Open Access This article is distributed under the terms of the Creative Commons Attribution 4.0 International License (http:// creativecommons.org/licenses/by/4.0/), which permits unrestricted use, distribution, and reproduction in any medium, provided you give appropriate credit to the original author(s) and the source, provide a link to the Creative Commons license, and indicate if changes were made.

\section{References}

Bhutto, A. W., Bazmi, A. A., \& Zahedi, G. (2013). Underground coal gasification: From fundamentals to applications. Progress in Energy and Combustion Science, 39, 189-214.

Burton, E., Friedmann, J., Upadhye, R. (2006). Best practices in underground coal gasification. Livermore, CA: Lawrence Livermore National Laboratory.

Couch, G. R. (2009). Underground coal gasification, IEA Clean Coal Centre. London: International Energy Agency.

DeGraeve, G. M., Overcast, R. L., \& Bergman, H. L. (1980). Toxicity of underground coal gasification condenser water and selected constituents to aquatic biota. Archives of Environmental Contamination and Toxicology, 9, 543-555. 
Edgar, T.F., Humenick, M.J., Kaiser, W.R., \& Charbeneau, R.J. (1981). Environmental effects of in situ gasification of Texas lignite. Project summary. US EPA; EPA-600/S7-81-035.

Friedmann, S. J., Upadhye, R., \& Kong, F. M. (2009). Prospects for underground coal gasification in carbon-constrained world. Energy Procedia, 1, 4551-4557.

Ghose, M. K. (2002). Complete physicochemical treatment for coke plant effluents. Water Research, 36(5), 1127-1134.

Kapusta, K., \& Stańczyk, K. (2011). Pollution of water during underground coal gasification of hard coal and lignite. Fuel, 90, 1927-1934.

Kapusta, K., Stańczyk, K., Wiatowski, W., \& Chećko, J. (2013). Environmental aspects of a field-scale underground coal gasification trial in a shallow coal seam at the experimental mine Barbara in Poland. Fuel, 113, 196-208.

Kapusta, K., Wiatowski, M., Stańczyk, K., \& Stańczyk, K. (2016). An experimental ex-situ study of the suitability of a high moisture ortho-lignite for underground coal gasification (UCG) process. Fuel, 179, 150-155.

Li, Y. M., Gu, G. W., Zhao, J. F., Yu, H. Q., Qiu, Y. L., \& Peng, Y. Z. (2003). Treatment of coke-plant wastewater by biofilm systems for removal of organic compounds and nitrogen. Chemosphere, 52, 997-100.

Liu, S., Li, J., Mei, M., \& Dong, D. (2007). Groundwater pollution from underground coal gasification. Journal of China University of Mining and Technology, 17, 0467-0472.

Maranon, E., Vazquez, I., Rodriguez, J., Castrillon, L., Fernandez, Y., \& Lopez, H. (2008). Treatment of coke wastewater in a sequential batch reactor (SBR) at pilot plant scale. Bioresource Technology, 99, 4192-4198.

Ozyonar, F., \& Karagozogly, B. (2015). Treatment of pre-treated coke wastewater by electrocoagulation and electrochemical peroxidation processes. Separation and Purification Technology, 150, 268-277.

Perkins, G. (2018a). Underground coal gasification - Part I: Field demonstrations and process performance. Progress in Energy and Combustion Science, 67, 158-187.

Perkins, G. (2018b). Underground coal gasification-Part II: Fundamental phenomena and modeling. Progress in Energy and Combustion Science, 67, 234-274.
Shackley, S., Mander, S., \& Reiche, A. (2006). Public perceptions of underground coal gasification in the United Kingdom. Energy Policy, 34, 3423-3433.

Shafirovich, E., \& Varma, A. (2009). Underground coal gasification: A brief review of current status. Industrial and Engineering Chemistry Research, 48, 7865-7875.

Smoliński, A., Stańczyk, K., Kapusta, K., \& Howaniec, N. (2013). Analysis of the organic contaminants in the condensate produced in the in-situ underground coal gasification process. Water Science and Technology, 67(3), 644-650.

Stuermer, D. H., Ng, D. J., \& Morris, C. J. (1982). Organic contaminants in groundwater near an underground coal gasification site in northeastern Wyoming. Environmental Science \& Technology, 16, 582-587.

Sury, M., White, M., Kirton, J., Carr, P., Woodbridge, R., Mostade, R., Chappell, M., Hartwekk, D., Hunt, D., \& Rendell, N. (2004). Review of environmental issued of underground COAL gasification; report COAL R272; DTI/pub URN 04/ 1880: Department of Trade and Industry technology (DTI); London.

Walters, E.A., Niemczyk, T.M. (1984) The effect of underground coal gasification on ground water. US EPA; EPA-600/S2-84123.

Wiatowski, M., Kapusta, K., Stańczyk, K., \& Stańczyk, K. (2019). Efficiency assessment of underground gasification of orthoand meta-lignite: High-pressure ex situ experimental simulations. Fuel, 236, 221-227.

Xuewen, J., Enchao, L., Shuguang, L., Zhaofu, Q., \& Qian, S. (2013). Coking wastewater treatment for industrial reuse purpose: Combining biological processes with ultrafiltration, nanofiltration and reverse osmosis. Journal of Environmental Sciences, 25(8), 1565-1574.

Yang, L. (2009). Modeling of contaminant transport in underground coal gasification. Energy \& Fuels, 23, 193-201.

Publisher's Note Springer Nature remains neutral with regard to jurisdictional claims in published maps and institutional affiliations. 